Article

\title{
Tragedy of the Commons, Business Growth and the Fundamental Sustainability Problem
}

\section{Edward J. Garrity}

Marketing \& Information Systems Department, Richard J. Wehle School of Business, Canisius College, 2001 Main St., Buffalo, New York, 14208, USA; E-Mail: garrity@ canisius.edu; Tel.: +1-716-888-2267; Fax: +1-716-888-2525.

Received: 6 August 2012; in revised form: 5 September 2012 / Accepted: 20 September 2012 / Published: 28 September 2012

\begin{abstract}
This paper reviews the major issues involved in Hardin's [1] tragedy of the commons, written over 44 years ago, and examines whether these issues are still relevant today. We assert that this model still provides important insight to aid in the solution to our global problems. In particular, we maintain that the underlying issues of growth against limits and bounded rationality are still not adequately recognized and addressed; this underlies many of the reasons for our unsustainable world. Examples from fisheries management are used to examine potential solutions and reveal weaknesses in current approaches. We show how our current, restricted mental models promote social injustice and blind us to developing sustainable solutions. Both the neo-liberal economic view of business that directly seeks growth and the new sustainable development view that indirectly supports growth are leading our global economy in the wrong direction and away from prosperity and sustainability. Current thinking has not realized Hardin's message that sustainability is of the class of no technology solution problems. We conclude with recommendations to radically advance a new world view and business paradigm.
\end{abstract}

Keywords: bounded rationality; business growth; common pool resources; growth against limits; social justice; sustainability; system thinking; tragedy of the commons

\section{Introduction}

In Garrett Hardin's seminal essay, the tragedy of the commons, Hardin illustrates a dilemma faced by mankind when confronted with the freedom to make individual choices in situations where the sum total of individual, rational decisions has ramifications for the common good. The main focus of his 
essay actually deals with the problem of unrestrained population growth. Hardin argues that the population problem belongs to the class of "no technology solution problems." He defines a technology solution as one that requires only a change in the techniques of the natural sciences, demanding little or nothing in the way of change in human values or ideas of morality [1]. The essential arguments for this case rest on several well understood concepts: (1) in a finite world with a given or reasonable level of technology, increases in the global population will result in a declining standard of living, or at some point "will greatly increase human misery;" (2) One cannot attempt "to provide the greatest good for the greatest number" because it is not mathematically possible to maximize for two or more variables at the same time [2]. If we attempt to maximize population then we have the problem with providing sufficient amounts of energy for this biological base. In addition, even if sufficient technology were developed to produce this level of energy (e.g. nuclear power, fusion, etc.) we then have to deal with the dissipation of this energy. Hardin seems to understand and implicitly advance the notion that a large and growing population will continuously push up against the limits of a finite planet.

The population problem is intertwined with Adam Smith's notion of the "invisible hand" or the idea that individuals' acting in their own self-interest in free markets will generate behavior that is in the public interest [1]. The contradiction to Adam Smith's invisible hand is provided by the following scenario:

The tragedy of the commons develops in this way. Picture a pasture open to all. It is to be expected that each herdsman will try to keep as many cattle as possible on the commons. Such an arrangement may work reasonably satisfactorily for centuries because tribal wars, poaching, and disease keep the numbers of both man and beast well below the carrying capacity of the land. Finally, however, comes the day of reckoning, that is, the day when the long-desired goal of social stability becomes a reality. At this point, the inherent logic of the commons remorselessly generates tragedy.

As a rational being, each herdsman seeks to maximize his gain. Explicitly or implicitly, more or less consciously, he asks, "What is the utility to me of adding one more animal to my herd?" This utility has one negative and one positive component.

1. The positive component is a function of the increment of one animal. Since the herdsman receives all the proceeds from the sale of the additional animal, the positive utility is nearly +1 .

2. The negative component is a function of the additional overgrazing created by one more animal. Since however, the effects of overgrazing are shared by all the herdsmen, the negative utility for any particular decision-making herdsman is only a fraction of -1 .

Adding together the component partial utilities, the rational herdsman concludes that the only sensible course for him to pursue is to add another animal to the herd. And another (...) but this is the conclusion reached by each and every rational herdsman sharing a commons. Therein is the tragedy. Each man is locked into a system that compels him to increase his herd without limit -in a world that is limited. Ruin is the destination toward which all men rush, each pursuing his own best interest in a society that believes in the freedom of the commons. Freedom in a commons brings ruin to all [1]. 
Both the population problem and the overuse of resources (tragedy of the commons) can be analyzed from the perspective of systems thinking. The next section explains systems thinking principles to help understand the situation and explicitly define the interconnected feedback structure involved.

\subsection{Systems Thinking}

A system can be defined as a set of interdependent components organized by design to accomplish one or more objectives [3]. Systems may be comprised of and organized by subsystems and each of these may interact with each other as well as with their environment and share information. One of the features of complex systems that make their behavior difficult to understand or complex is that components, subsystems and systems are so interconnected. It is difficult to change just one thing (component) without it having an effect on many other components and systems.

A more useful and truer picture of our complex systems will show the feedback structure involved. Although systems may involve many hundreds of variables or components variously interconnected, the long-run dynamic behavior of complex systems is generated by the interaction of just two basic types of feedback loops, either reinforcing feedback that increases or amplifies changes or balancing feedback loops that counteract or oppose change [4]. Figure 1 illustrates a reinforcing feedback loop where births lead to a higher population. This is a reinforcing feedback relationship and therefore a higher population (increase) also leads to higher births (increase) (i.e., the ' + ' symbol indicates the same direction of change, see Figure 1b). The graph (Figure 1a) demonstrates that this produces an exponential growth pattern. Such a graph over time can be generated from all reinforcing feedback loops: for example, the higher the amount on deposit in the savings account will lead to higher interest income that adds to a higher bank balance. Reinforcing feedback loops can also operate to produce a decay pattern over time. If a population is declining due to greater predation, hunting (or fishing) or other influences then a lower population level leads to a lower net birth rate. Thus, a decrease in births leads to a decrease in the population (i.e., the ' + ' symbol indicates the same direction of change) which then leads back to a decrease in births.

Naturally, rabbits do not generate infinite or astronomical population levels as shown in Figure 1a. Eventually limits are reached. In Figures $2 \mathrm{a}$ and $2 \mathrm{~b}$, the reinforcing loop, R1, generates rapid growth in the rabbit population in the beginning, but the balancing loops, B2, and B3 and B4 (see Figure 2b), begin to dominate as the population pushes up against the carrying capacity of the environment (the '-' symbol indicates the opposite direction of change, so as the population increases the resource adequacy decreases. The reverse would also be true, if the population was decreasing then the resource adequacy would be increasing). When resources decrease and balancing feedback loops dominate, we observe the common S-shaped behavior-over-time graph (Figure 2a). This pattern is quite common in many natural populations since there are often many limiting factors to place a check on runaway (exponential) population growth. 
Figure 1. Graph and Causal Loop Diagram of Reinforcing Feedback; (a) Rabbit Population Graph, Behavior over Time of Reinforcing Feedback; (b) Causal Loop Diagram (CLD) of Reinforcing Feedback.

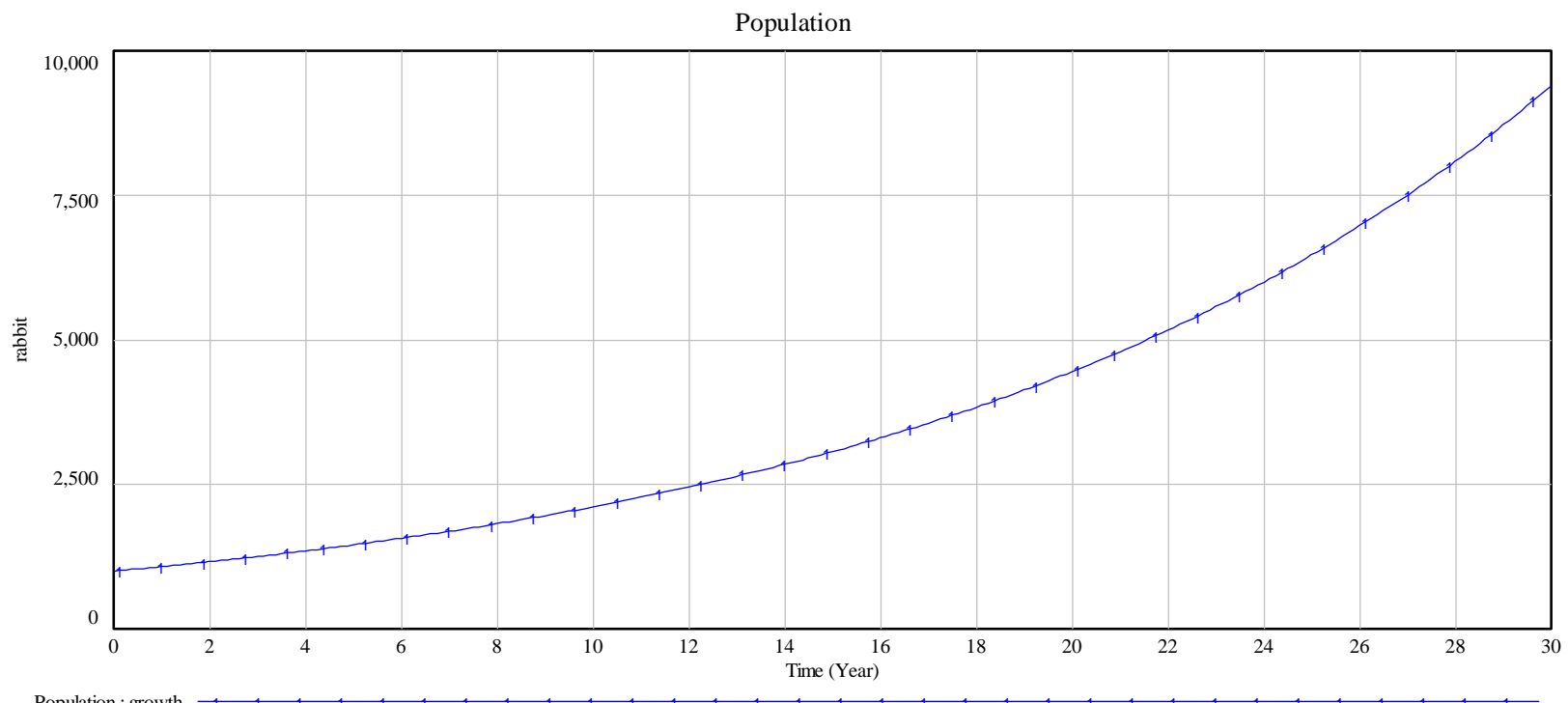

(a)

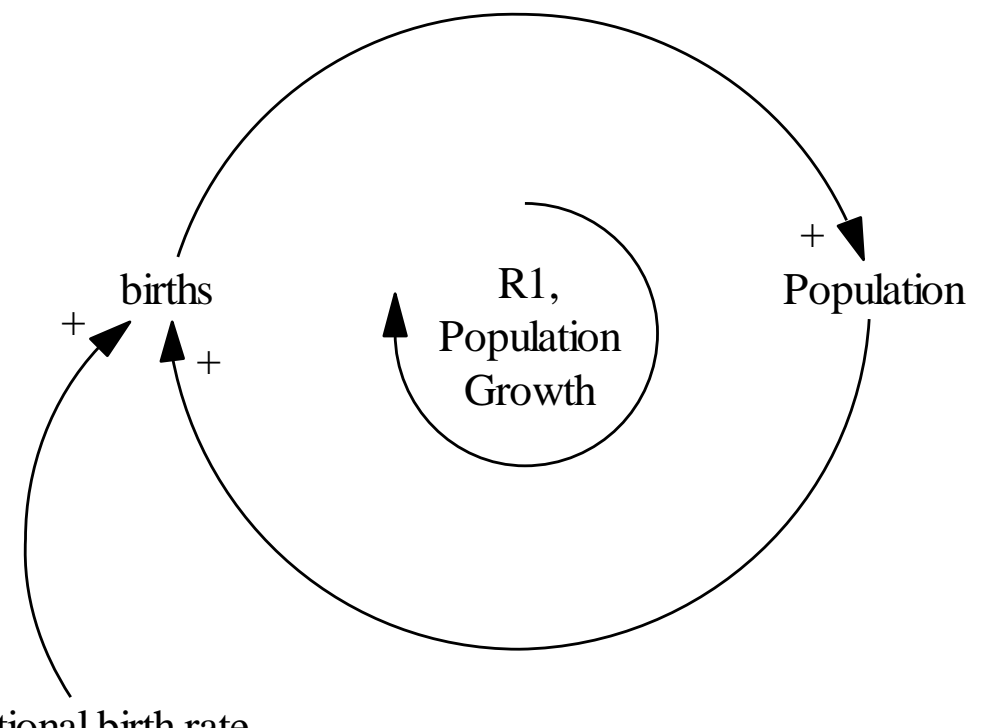

fractional birth rate

(b) 
Figure 2. Graph and Causal Loop Diagram of Reinforcing and Balancing Feedback; (a) Rabbit Population and Behavior-Over-Time Graph; (b) Causal Loop Diagram of both Reinforcing and Balancing Feedback, Rabbit Population.

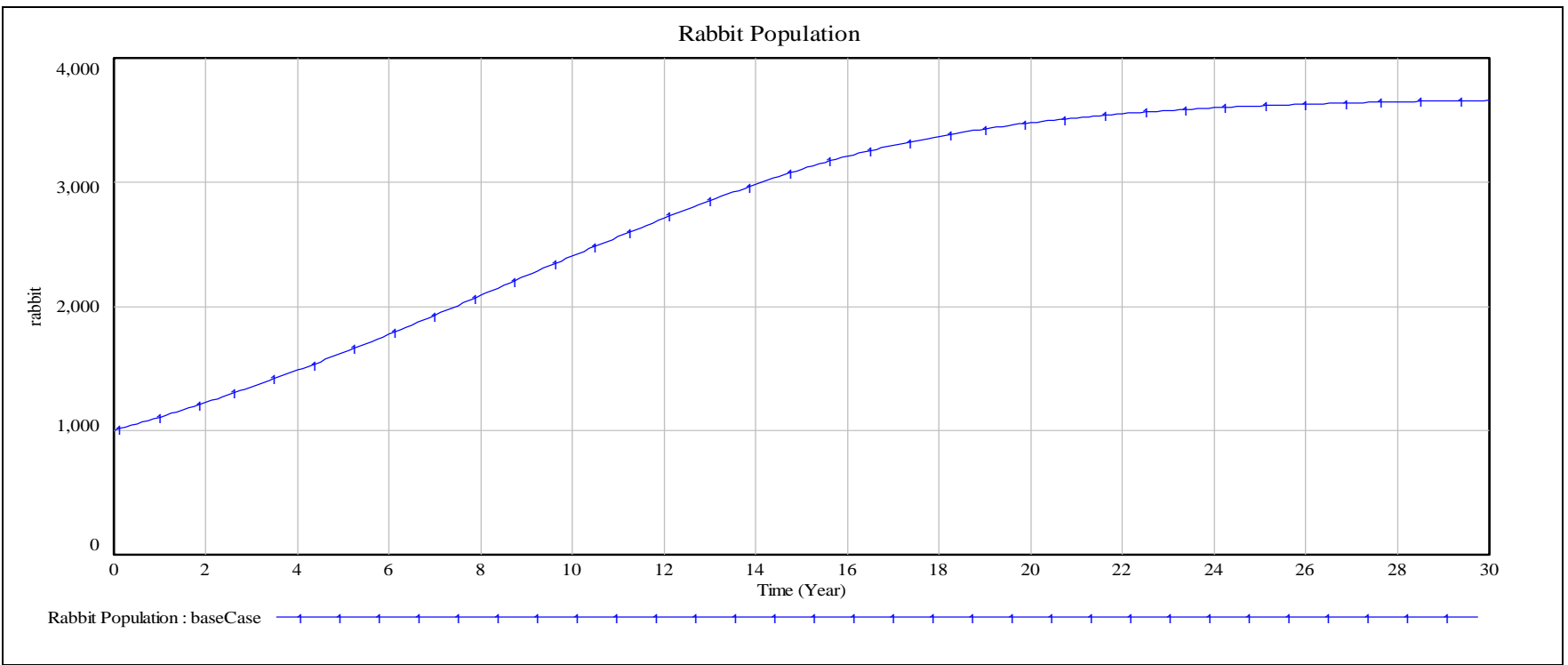

(a)

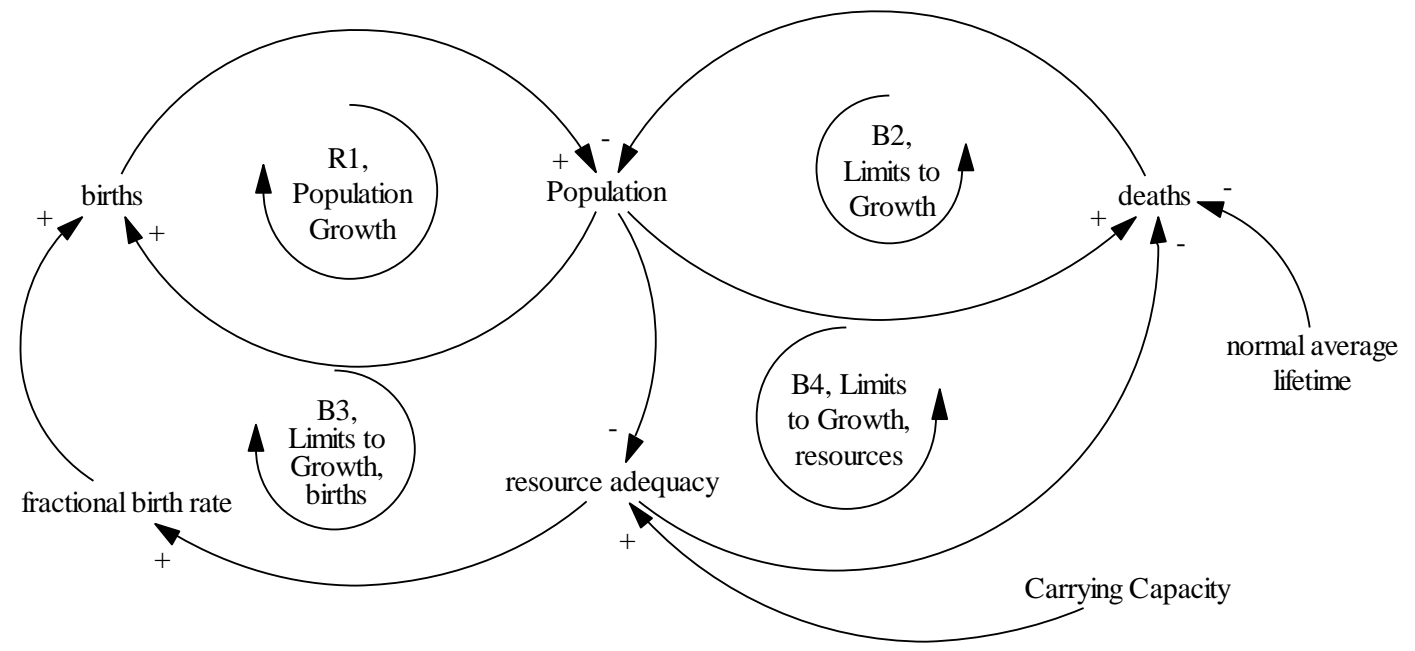

(b)

\subsection{Systems Thinking and Tragedy of the Commons}

Figure 3 displays the tragedy of the commons as a causal loop diagram. Reinforcing loops R1 and R2 show the initial economic behavior of individuals in an open access, common pool resource situation. Actor A and actor B both pursue activities, such as adding cattle to the pasture and both actors receive economic benefit. Although total activity increases there is little or no loss in productivity since they are not near the resource limit and there is little or no effect on the "gain/individual activity." Eventually however, productivity drops as they move closer to the resource limit and actors A and B are faced with a decision. If they do what is "best for all concerned" then balancing loops B3 and B4 should dominate and activity should cycle down to an acceptable level. However, each actor, operating under economic rationality decides that they will receive the 
full-benefit of the activity but only bear a fraction of the cost. Thus, each actor is compelled to add more activity and reinforcing loops R5 and R6 dominate. Additionally, after a delay, the resources limit itself erodes (such as cattle overgrazing and destroying the regenerative capacity, R7 loop) which further decreases the "gain/individual activity." The end result is economic ruin for all as growth activity in the commons exceeds the carrying capacity.

In Figure 3 we see the two dominant features of the tragedy of the commons: (1) growth against limits (in reinforcing loops R1 and R2 against resource limits), and (2) individual decision making that is dominated by bounded rationality (in reinforcing loops R5 and R6). Bounded rationality is a fundamental feature of individual decision making in organizations where individuals make rational decisions in situations where the choice set is simplified [5]. In organizations, simplification is necessary because of the large number of feasible choices and the large amount of information required for monitoring and coordinating actions [6]. In a tragedy of the commons dilemma, individuals make rational, local decisions based on their limited information. In essence, there is missing information feedback on the state of the commons resource itself and also on the behavior of the other users [7]. Bounded rationality means that seemingly rational choice by individuals as decentralized decision makers does not guarantee that their choices are consistent and mutually supportive [6].

In order to avoid tragedy Hardin concluded that the commons must either be privatized (free market) or kept as public property where rights to entry and use could be allocated and managed (a form of socialism) $[1,8,9]$. The next section reviews the solutions advanced since the original paper.

Figure 3. Tragedy of the commons as a Causal Loop Diagram.

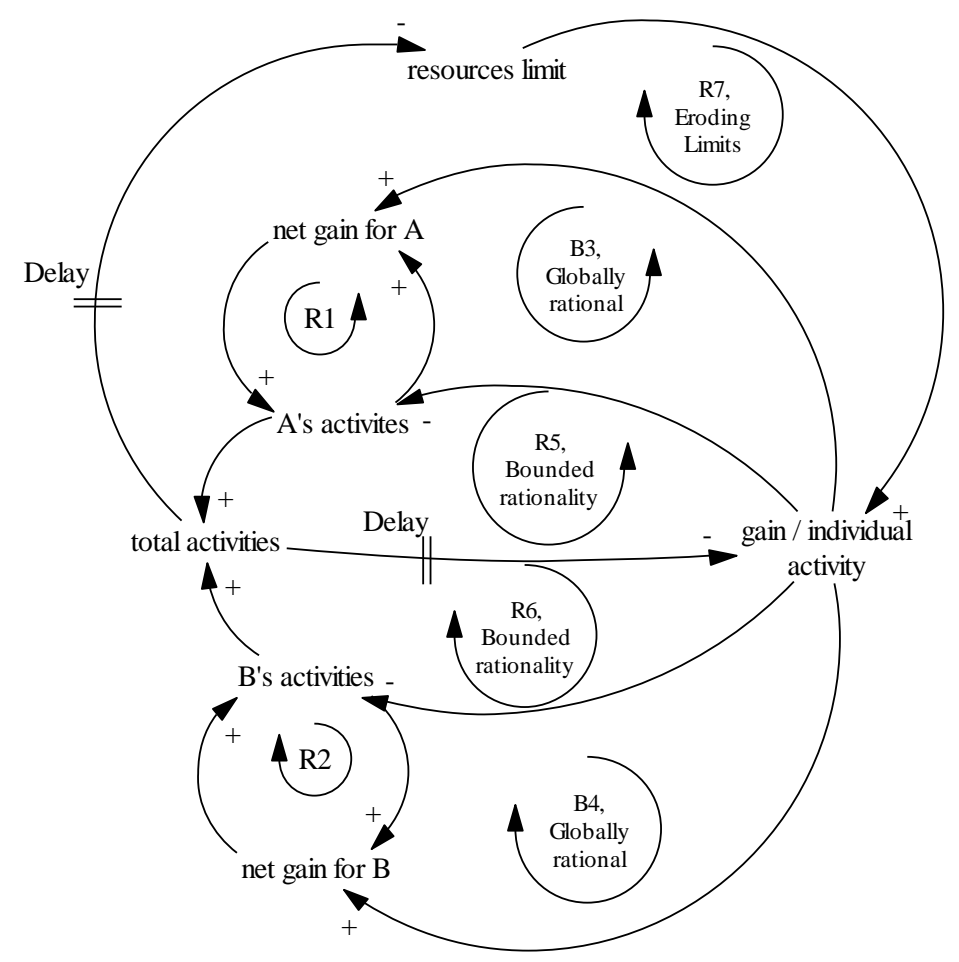




\section{Common Pool Resource Challenges}

\subsection{Local Solutions to Common Pool Resource Problems}

Ostrom and her colleagues [10] viewed Hardin's conclusions as painting a dark, pessimistic view of commons resources and have disputed his implicit view that commons problems require some type of strong central control. In fact, Ostrom [11,12] and others [8] have documented numerous cases where local users have been able to self-organize to manage common property resources. Researchers have stressed that to properly understand commons problems one must separate concepts related to resource systems from those that concern property rights. The term common pool resource (CPR) is used to denote resources where: (1) exclusion of users through physical and institutional means is especially costly (exclusion property), and (2) exploitation by one user reduces resource availability for others (subtractability property) [13].

The prediction for a tragedy of the commons dilemma rests on the belief that all resource users are selfish, norm-free, and maximizers of short-run results [10]. This view of humanity, that we all adopt a narrow, self-interested, short-term perspective may hold true in many settings, however, people can also use reciprocity to overcome social dilemmas [14,15].

Reciprocal cooperation can be established, sustain itself and grow if the proportion of people in a community who behave in a narrow, self-interested way is not too high [14]. Solving CPR problems involves two distinct complications: (1) restricting user access to the resource and (2) creating incentives for users to invest in the resource instead of overexploiting it. When social interactions enable those who use reciprocity to gain a reputation for trustworthiness, others will be willing to cooperate with them to overcome CPR or tragedy of the commons situations, which then leads to increased gains for themselves and their offspring [14]. Thus, close-knit communities of people that can identify one another are more likely than diverse, separated groups of strangers to use trust, reciprocity, and reputation to develop norms that restrict access and create incentives for proper use [11].

However, the ability of local communities to develop social institutions to manage CPRs may not be easily converted or scaled-up to broader or global social settings. In many cases, environmental resources span wide geographic areas and may encompass various political boundaries. When diverse groups are present or there are large numbers of participants, organizing may be more difficult and many of the requisite characteristics of local CPR solutions may be absent [11].

\subsection{Privatization (Free Market) as a Solution to Common Pool Resources}

A common pool resource is any area such as a lake, an irrigation system, a forest, or in the case of global resources, the atmosphere or oceans, where it is difficult to exclude users (exclusion) and where one person's consumption or exploitation of resource units makes those units unavailable to others (subtractability) [13]. Common pool resources are unique in that the difficulty in excluding users is a characteristic shared with public goods but the subtractability of the resource is shared with private goods [11].

A fishery is an example of a common pool resource because it is difficult to exclude users and harvesting fish by one user means that those fish will not be available to others. The appropriation 
problem is the natural incentive for individual users to appropriate more resource units when acting independently than if there were some way of cooperating and coordinating appropriation among the group of users [11].

One such scheme of coordinating activities and cooperating is provided by (virtual) privatization in the form of individual transferrable quotas (ITQs).

\subsubsection{An Example: Catch Shares and Individual Transferable Quota (ITQ) Fisheries}

Catch shares are allocated privileges to land a portion of the total allowable catch (TAC) $[16,17]$. ITQ programs are a form of catch shares where the shares are transferrable; share-holders have the freedom to buy, sell, and lease quota shares [18,19].

Many researchers have hailed ITQ programs as the best solution for fisheries as it combines economic success while also avoiding overexploitation. The success of ITQ programs is linked to the increased incentives for long-term management due to a form of property rights or virtual ownership. Since the economic value of quota shares increases when fish stocks are well managed, ITQ shares create an economic incentive for stewardship [18-22]. ITQ programs have shown success toward many goals including biological sustainability and economic profits and output [16,19,21-23]. In addition, Costello et al. [17] examined over 11,000 global fisheries and found evidence that ITQ managed fisheries are less prone to collapse.

Despite such claims of success ITQ programs have several shortcomings. First, if ITQ rules allow for large external shareholders then local community fishermen can lose their livelihoods. Fortunately, through careful planning, rules to restrict share ownership can prevent this problem and can help local communities to thrive and promote social equity. Second, cheating activities benefit individuals directly but the negative utility of cheating is shared by all. In other words, the classic tragedy of the commons is not entirely eliminated. Such activities include quota busting (catching above quota) and the concomitant misreporting of catch, as well as high-grading (throwing away under-valued catch so it doesn't count toward quota). Thus, critics argue that ITQ programs do not create true property rights. Holding a quota share only provides a right to harvest, but confers no real control over the resource itself [16,24,25]. Third, the cost of any short-term sacrifice is borne by the individual. However, long-term benefits that accrue from stock rebuilding are shared by all fishery participants.

\subsubsection{Rebuilding Global, ITQ Fisheries}

Rebuilding global fisheries is a problem for free market approaches like ITQ programs. Although there has been strong evidence that ITQ programs have been successful at preventing fisheries collapse [17] there has also been evidence that ITQs are less helpful in rebuilding stock levels. Chu [20] found that in 20 stocks managed by ITQ systems, 12 stocks showed improvements in stock biomass but 8 of the 20 stocks continued to decline after ITQ implementation. Some of the declines in fish stocks may be due to inappropriate TACs or low levels of enforcement and harvest compliance [20].

Rebuilding fish stocks with free market approaches brings to light the fundamental dilemma between private interests and public interests. Fishermen must be concerned with their short-term 
results and profits while in contrast, public interests are primarily with managing resource stocks for the long-term to benefit the common good [26].

The perspective of public management of fish resources for the long-term, common good means that a more conservative or precautionary TAC must be used. Figure 4 displays a comparison of long-term, total fishery profit for two TAC policies that were generated from a computer simulation of an ITQ fishery (see [26]). The precautionary policy (lower TAC) allows the fish stock to rebuild and produces a higher long-term pattern of total fishery profit. Precautionary TAC policy is thus judged to be far superior for the public and common good.

However, since ITQ holders must remain profitable and competitive, discounted cash flow results will dominate their decision process. Because precautionary TAC policy produces a "worse before better" pattern ITQ fisheries will resist management approaches that seek rebuilding.

Figure 4. Rebuilding fisheries with precautionary policy, adopted from [26].

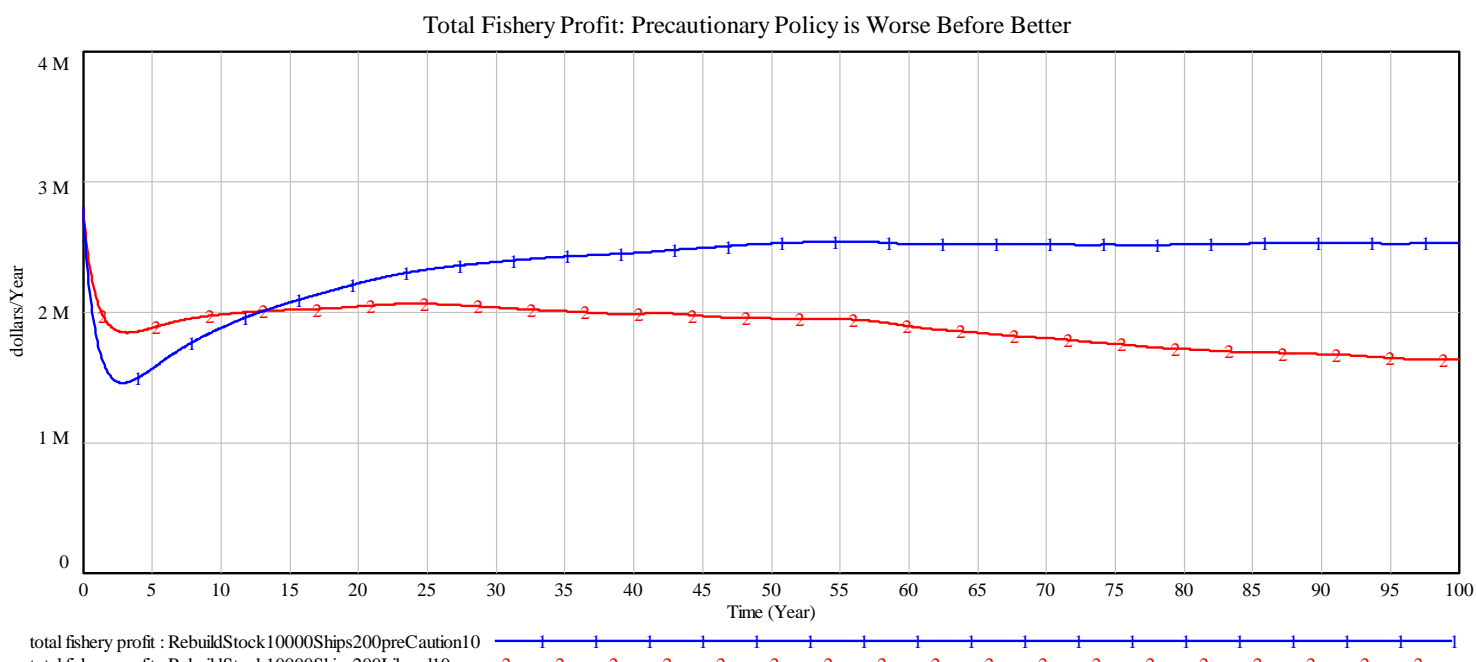

total fishery profit : RebuildStock10000Ships200preCaution10
total fishery profit : RebuildStock 10000 Ships 200 Liberall0

Figure 5 displays the CLD that summarizes some of the inherent shortcomings with ITQ programs, and the dilemma between short-term, private interests of fishermen and the local community versus the public and long-term goals of fishery management.

Figure 5. Policy resistance, diffused responsibility, and ownership, adopted from [26].

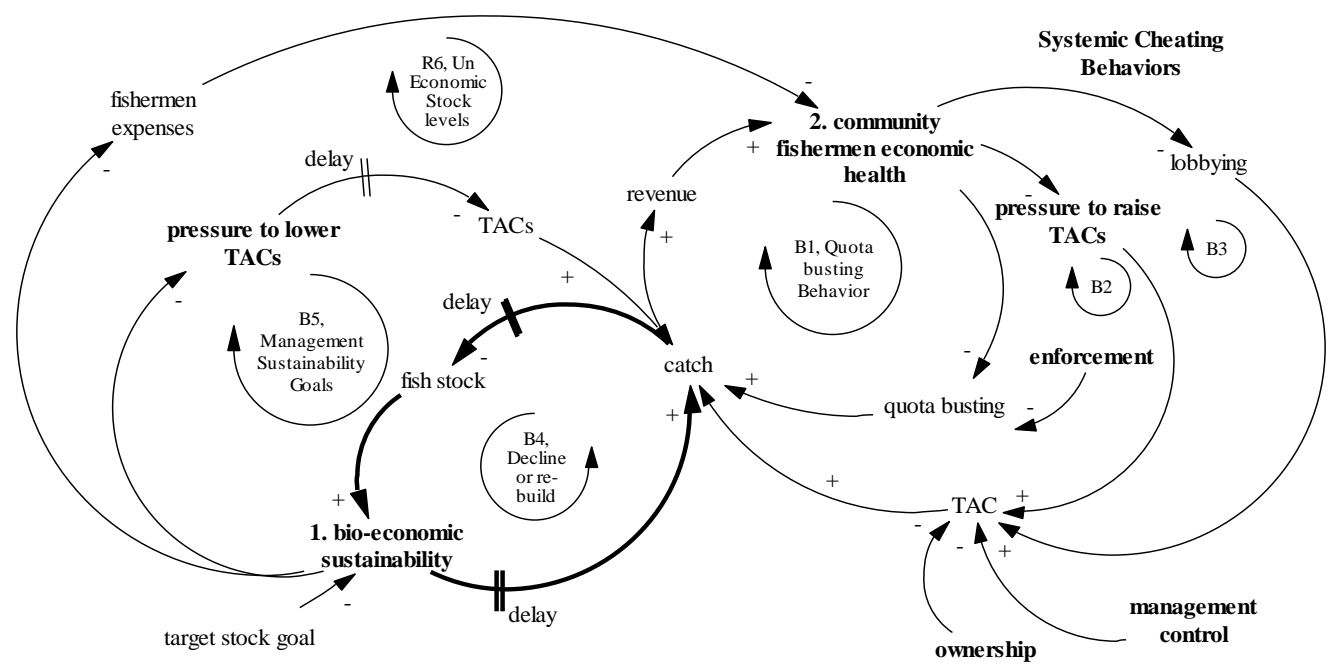


In Figure 5, if we examine a stock rebuilding situation with decreasing bio-economic sustainability (labeled variable 1) relative to a target stock goal, we can then trace this to an increase in pressure to lower TACs, then to a decrease in TACs, causing a decrease in catch, and to an increase in the fish stock, finally leading back to an increase in bio-economic sustainability. In essence, tracing through this causal path shows fishery management's response to this problem or gap between the desired and actual state. Of course, management's actions are not performed in isolation, but rather they are interdependent and linked to impacts in the fishery community. Thus, lower catches also lead to lower revenue and reduced levels of community fishermen's economic health. Reductions in economic health can set off various systemic cheating behaviors such as lobbying the political authority, applying direct pressure on management to raise TAC, and quota busting behavior (illegal catches above quota). All of these actions are policy resistance as the local community responds to their short-term economic interests [26].

\section{Global Challenges: Environmental Impact, Sustainability and the Global Economy}

The tragedy of the commons has been viewed by researchers as primarily a dilemma facing users of common pool resources. However, a number of fundamental concepts that underlie the tragedy of the commons can be used to provide insight into global problems of sustainability. Sustainability is broadly defined as the ability for humans and other life forms to flourish on the Earth forever [27]. The primary global sustainability challenge is to find ways to limit our environmental impacts and live within the finite limits of the planet.

An important theory on how economies can achieve sustainability is the viewpoint of environmental Kuznet curves (EKC). The EKC theory is that there is an inverted U-shaped relationship between economic development and environmental impacts. Specifically, the theory predicts that environmental impacts will increase in early economic stages of development, but as economies mature and technologies are adopted, impacts will level-off and decline (see [28-30]). In essence this theory views environmental quality as a luxury good that more advanced societies can afford. Additionally, both ecological modernization theory (EMT) [31], and industrial ecology (IE) [32] also share the belief that material and energy flows of modern production systems can be dramatically decreased [33]. The three theories support the notion that economies can grow and still maintain the same level (or even less) of environmental impacts through advances in technology.

We assert that these theories are simply wrong in the belief that economic growth can continue without increasing negative impacts on the environment and taking us further away from sustainability.

\subsection{Environmental Impact and Growth}

Hardin's basic arguments regarding the population problem also apply to the general problem of global environmental impact and sustainability. Environmental impact is defined as increases in use of resources (renewable and non-renewable), and degradation of the environment (land, water, air, and resources). The classic IPAT formula defines environmental impact as arising from the interaction of 3 major factors $[34,35]$ : 


$$
\mathrm{I}=P \times \mathrm{A} \times \mathrm{T}(\mathrm{IPAT})
$$

Where $\mathrm{I}=$ environmental impact, $\mathrm{P}=$ population, $\mathrm{A}=$ affluence, and $\mathrm{T}=$ technology.

The use of the IPAT formula typically involves examining a specific impact, such as resource use (e.g. oil resource), from a source:

$\mathrm{I}=\mathrm{P}($ people $) \times \mathrm{A}(\mathrm{GDP} /$ people $) \times \mathrm{T}($ billions of barrels/GDP $)$

With resulting impact in terms of billions of barrels used.

Alternatively, another specific impact would be the result of human activity dumping a waste or byproduct into an environmental sink, such as $\mathrm{CO}_{2}$ output to be absorbed by various sinks (ocean, atmosphere, rainforest):

$$
\mathrm{I}=\mathrm{P}(\text { people }) \times \mathrm{A}(\text { GDP/people }) \times \mathrm{T}\left(10^{6} \text { metric tons } \mathrm{CO}_{2} / \text { GDP }\right)
$$

With resulting impact in terms of $10^{6}$ metric tons $\mathrm{CO}_{2}$ produced.

Environmental impacts contribute to unsustainability. Sustainability means (1) achieving reasonable rates of usage for renewable resources, such as fisheries, that are less than or equal to their natural regeneration; (2) pollution, garbage and byproducts of consumption cannot be generated faster than they can decay and be broken-down into harmless components; and (3) in the long-run we cannot use non-renewables at all [36,37]. Therefore, the IPAT formula serves as a useful framework for understanding sustainability.

Environmentalists emphasize the importance and the severity of the sustainability challenge due to the unrelenting growth in both global population (see Figure 6) and affluence.

Figure 6. World Population.

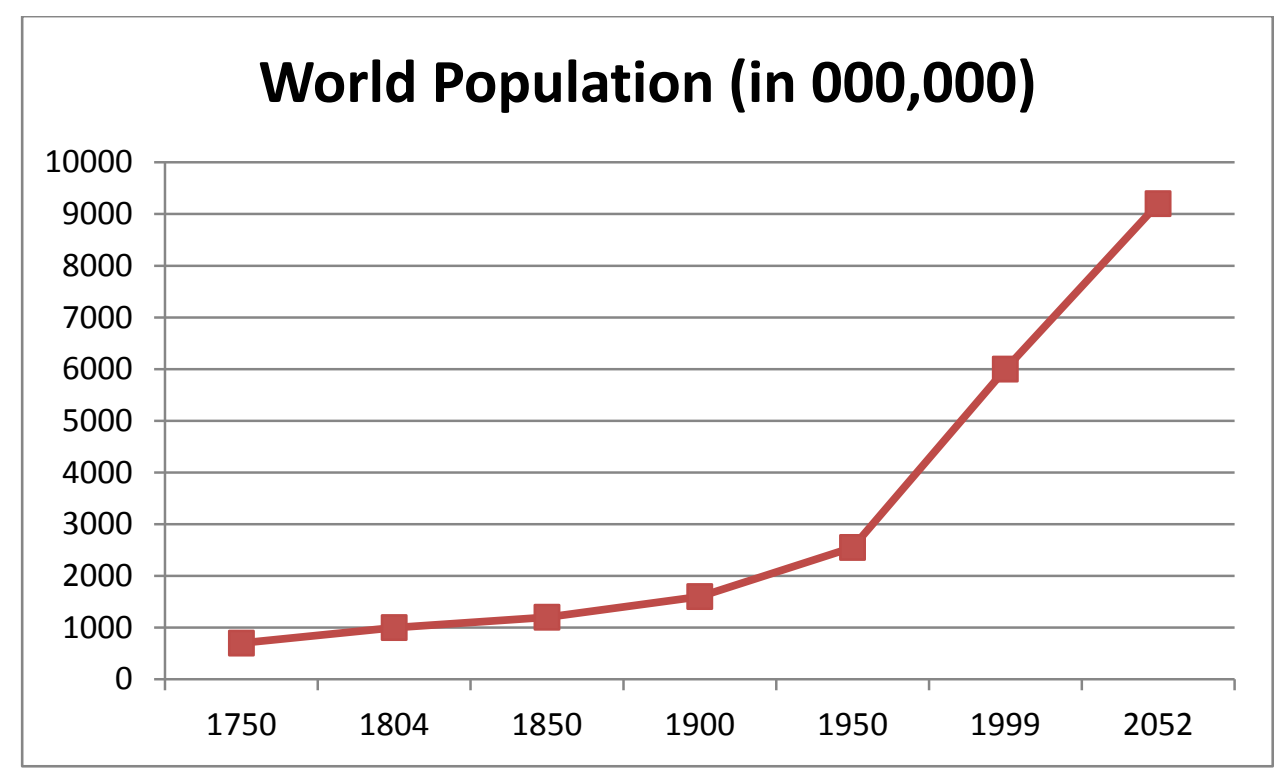

Note: The graph's X-axis is scaled in approximately 50 year equal intervals, including projected population in 2052 (see [38-40]). 
World population is currently growing at approximately $1.2 \%$ per year. Although the annual growth increase (inflow) in world population peaked around 1989 to 1990 and the annual growth rate peaked in about 1963 to 1964 at $2.2 \%$, the world growth rate, while declining, is still projected to be $1.2 \%$ to $0.5 \%$ for the next 40 years (see [40]). Population growth is exponential growth with a doubling time of 70 years (at $1 \%$ growth). Reductions in the growth rate in world population are partly due to increases in affluence.

Real Gross World Product (as a measure of affluence) grew at 3.5\% per year from 1950 to $2009[36,41,42]$. Continuing at this rate would mean that World GDP doubles every 20 years and the world economy will be four times greater in 2052 than today. Such growth in population and affluence places a great burden on technology to make enough significant advances to counterbalance the resulting environmental impacts.

Environmental Kuznets theory states the contradictory assumption that growing levels of affluence are in fact necessary to develop the sufficient level of technology to mitigate impacts. Testing for environmental Kuznet effects however is not possible with the IPAT formula. The basic IPAT formula has been criticized because of its limitation as an accounting equation that does not permit hypothesis testing between anthropogenic factors and impacts [43,44]. The IPAT formula assumes a proportional functional relationship so that for example, a doubling of population will lead to a doubling of impact. The STIRPAT formula on the other hand is a stochastic model that allows for testing of non-proportional effects on impact and also non-monotonic ones as in the environmental Kuznets curve hypothesis. However, while the STIRPAT model is most useful for examining precise impacts, ecological elasticities (the proportional change in environmental impacts due to a change in a driving force) and those impacts due to other social factors, it also requires extensive data collection with empirical testing [43].

The usefulness of environmental Kuznets theory rests on the idea that technology can change sufficiently to offset changes in the driving forces of affluence, industrialization and population increase. However, the ability to change technology does vary across environmental impacts $[33,43]$. Thus, technological change can reduce the use of one resource leading to a reduction in one environmental impact, but through substitution the change could also result in a different set of cascading environmental impacts [33]. Using STIRPAT to prove that environmental Kuznets theory helps prevent unsustainability would potentially require testing thousands of environmental impacts. Further, nations can externalize environmental impacts by importing resources and exporting pollution. Therefore, addressing whether technology changes will be sufficient to compensate for environmental impacts due to increased industrialization requires either empirical testing with a comprehensive measure of impacts or the use of IPAT to give a general sense of overall impact.

Despite drawbacks with empirical testing, IPAT's strengths include its grounding in ecological principles, IPATs clear and parsimonious specification, and its utility for illustrating how changes in driving forces can alter impacts [43]. Thus, a second, simpler approach than empirical testing with a comprehensive measure is to use the IPAT formula to provide a rough estimate of the amount of technological change necessary to offset changes in affluence and population. Using the IPAT formula we address the question: "Given current trends in population and affluence, what level of technology will be necessary just to keep environmental impacts constant?" First, we estimate a change in world population from a present day estimate of 7 billion (2012) to approximately 9.2 billion in 2052 (using 
U.S. Census data, see [40]). Second, using the rate of growth of world GDP of 3.5\%, affluence will be four times greater in 2052. Third, we rearrange the IPAT equation to solve for technology change required (pp. 15-16, [45]):

$$
\begin{aligned}
& \mathrm{P}_{2012} \times \mathrm{A}_{2012} \times \mathrm{T}_{2012}=\mathrm{P}_{2052} \times \mathrm{A}_{2052} \times \mathrm{T}_{2052} \\
& \mathrm{~T}_{2052} / \mathrm{T}_{2012}=\mathrm{P}_{2012} / \mathrm{P}_{2052} \times \mathrm{A}_{2012} / \mathrm{A}_{2052} \\
& \mathrm{~T}_{2052} / \mathrm{T}_{2012}=(1 / 1.31) \times(1 / 4)=1 / 5.24
\end{aligned}
$$

Thus, in order to keep environmental impacts at the same level as year 2012 we will need to use technology to reduce impacts from industrial production and consumption by a factor of 5 times present efficiency levels.

\subsection{Eco-Efficiency and Sustainability}

The next logical question is: "Are changes in technology on the order of 5 times more efficiency practical?" In order to address this question we can expand on the original IPAT equation (see [46]):

$$
\mathrm{I}=\mathrm{P} \times(\mathrm{GDP} / \mathrm{P}) \times(\mathrm{Q} / \mathrm{GDP}) \times(\mathrm{R} / \mathrm{Q}) \times(\mathrm{I} / \mathrm{R})
$$

Where, $\mathrm{I}=$ impact, $\mathrm{P}=$ population, $(\mathrm{GDP} / \mathrm{P})$ is per capita affluence, and $(\mathrm{R} / \mathrm{Q}) \times(\mathrm{I} / \mathrm{R})$ is technology, and where $\mathrm{Q}$ is the quantity of goods and services delivered / time, and R is the quantity of resources used to deliver those goods and services. The term $(\mathrm{R} / \mathrm{Q})$ is the resource intensity and $(\mathrm{I} / \mathrm{R})$ is the impact per unit of resources used. Rearranging Equation 3 produces:

$$
\mathrm{R}=\mathrm{Q} \times(\mathrm{R} / \mathrm{Q})
$$

Equation (4) states that the resources consumed (R) are equal to the quantity of goods and services delivered $(\mathrm{Q})$ times the resource intensity $(\mathrm{R} / \mathrm{Q})$. Resource productivity or eco-efficiency is the inverse of resource intensity or $(\mathrm{Q} / \mathrm{R})$. Thus the resources used in production and consumption can be stated as $\mathrm{R}=\mathrm{Q} \times 1 /(\mathrm{Q} / \mathrm{R})$ or:

$$
\mathrm{R}=\mathrm{Q} \times 1 /(\text { eco-efficiency })
$$

Techno-optimists believe that resource use can be greatly reduced and that increases in population and affluence can, in many cases, be balanced by improvements to the environment offered by technological systems [35]. However, there is a counter-argument to this line of thinking. The Jevons paradox is the principle that as technology advances and leads to increases in the efficiency of resource utilization, consumption of that resource will also increase [47,48]. Thus, actual savings in resource use means that $(\Delta \mathrm{Q} / \mathrm{Q}<\Delta$ eco-efficiency/eco-efficiency), or the relative efficiency gain must outpace the relative increase in consumption [45]. To test this claim, Dahmus and Gutowski [49] collected data and compared major product categories from materials, transportation, energy generation, and food production over long time intervals (all time-series greater than 40 years). They found that, in all cases, consumption outpaces gains from efficiency by a wide margin. 
In addition, the second approach of empirical testing with a comprehensive impact measure was performed by York et al. [33]. They examined cross-national variation in the ecological footprint (EF) of nations per unit of GDP to address the question: "Can improvements in efficiency counterbalance environmental impacts of economic development?" They found that eco-efficiency does in fact increase as affluence rises, consistent with EKC theory. However, while they found that eco-efficiency is generally higher in developed nations, they also found that this level is not sufficient to offset the high resource demands that come with affluence. Their overall findings are that further modernization of production (increased technology) is unlikely in itself to lead to sustainability, at least in the present global context. Further, in the short-term at least, modernization and economic development are likely to place additional burdens on the environment. Generally, their study suggests that efforts to improve the efficiency of production will need to be used with other policies that take into account the underlying forces behind production and consumption.

The Jevons paradox originated from observations of market forces, specifically consumer reactions to market influences and it provides important insight regarding production and consumption [48]. When technology advances allowed for more efficient uses of coal, the supply of coal increased but this was followed by price adjustments in the market. Consumers reacted to lower prices by adjusting their behavior and increasing their demand. The same principle has been observed in the U.S. in the last several decades (see [50]). Motor vehicles have become less polluting and have achieved higher fuel efficiency. However, consumers have adjusted by acquiring more vehicles, driving more miles and switching to larger vehicles (e.g. sales of sport utility vehicles have soared). Such reactions from markets to changes in technology reflect more general phenomena of systems: policy resistance (see Appendix 1). It is therefore useful and necessary to examine the underlying system structure involved with consumption, production and technology.

\subsection{The Business Industrial Growth (BIG) Model}

It appears that technological change should be viewed as a necessary but not a sufficient condition for achieving our goals of sustainability [50]. Schor [50] argues that a purely technological approach will fail to achieve the goals of sustainability because the incentives to increase the scale of consumption are too powerful. In order to examine these forces in greater detail and better understand their dynamic interplay, we constructed a causal loop diagram of the important business relationships (Figure 7).

There are a number of well-known causal factors that help make up a common, mental model of consumption, production and technology. For example, it is conventional wisdom that businesses should reinvest profits into the business and deploy technology to make operations more efficient. Increased specialization from technology and scale economies will cause lower variable expenses. Lower variable expenses then enable lower, competitive pricing strategies. In addition, companies seek increased size and specialization from growth in order to provide leverage for increased innovation. More innovation allows for new products and product improvements (higher quality) that lead to competitive advantages in the marketplace. Each of these business actions drives higher volume which then feeds the reinforcing feedback loop to higher profits. Higher profits can then be used to drive further investments. 
While few businessmen would argue with these conventional beliefs, what are often missing in many mental models are the feedback loops that produce the behavior over time. People tend to view the world in simple cause-effect relationships but fail to see the many interconnections that produce endogenous impacts [4,51]. What is not widely understood but implicit within business people's mental models are the mutually reinforcing feedback loops that connect business and consumer behavior (Figure 7). Increased consumption should satisfy consumers and lead to higher levels of well-being. However, consumption is not equal across parts of society and "competitive consumption" itself drives further consumption [52]. In Figure 7, Loop B1 portrays a balancing feedback loop where increases to consumer A's material wealth decreases their relative wealth gap as compared with consumer B. As this gap decreases it leads to an increase in consumer A's happiness which should then reduce further purchasing below what it would have been otherwise. However, even among consumers who fall within the top income and consumption bracket, more consumption brings (fleeting) happiness but it also fuels the desire for complementary products. Purchasing a big screen television eventually leads to happiness but also to the desire for a high quality, high definition digital service, and a better set of speakers to render the high quality signal, and so on. Thus, reinforcing feedback loop R2 dominates leading consumer A to purchase more products. Meanwhile, as consumer A's relative material wealth gap decreases, this leads to a decrease in consumer B's happiness. This triggers balancing feedback loop B3 as consumer B attempts to reduce their relative material wealth gap through purchasing more products. This dynamic portrays a competitive consumption pattern when consumer A's material wealth exceeds consumer B's material wealth. The bold-faced arrows represent the dominate feedback loops in this case. However, a similar pattern also applies when consumer B's material wealth exceeds consumer A's, similar to an "escalation" system archetype pattern (e.g. "the cold war arms race").

The business industrial growth model is intended to provide a useful framework to examine the mutual interdependencies between business and consumer (macro) behavior. Both business and consumer behavior are much more complicated and the model certainly lacks detail and completeness. Specifically, the model only portrays business investment at a very high level with a focus on technology and workforce investments. While all models are wrong in some aspect, (see pp. 847-853 [4]), this model is useful for its intended purpose and for highlighting the importance that business size plays in the competitive marketplace. Not only do companies seek the benefits of specialization to remain competitive but an additional benefit of size means that companies gain increased bargaining power among suppliers and can command better resource and component prices (i.e. quantity discounts). 
Figure 7. Business Industrial Growth Model.

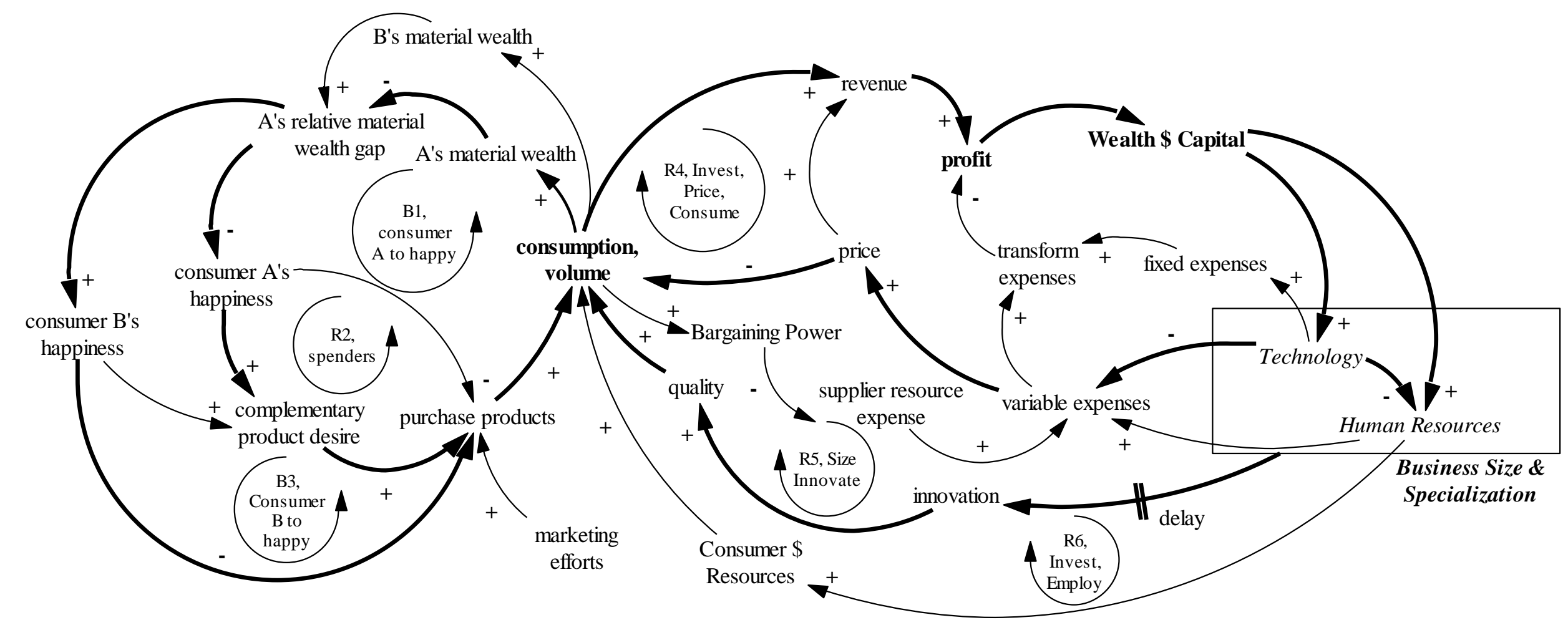

Notes: Bold arrows are used to document dominant feedback loops and important feedback loops are labelled. 


\subsubsection{The Problems of Growth: Social Justice and Global Impact}

The business industrial growth model is a pervasive force in developed economies. Small entrepreneurial firms seek business growth for the same reasons as large firms. Business size and specialization confer competitive advantages. However, first mover advantages that apply to competitive markets also apply to the global market. Firms in developing nations that have a significant delay in establishing the reinforcing feedbacks of the BIG model have less capital for business investment. Competitive disadvantages require shortcuts. The net effect: the wages in foreign manufacturing are kept artificially low and environmental effects from manufacturing remain externalized [50]. In other words, manufacturing in developing nations remain competitive in the global market through: (1) cutting-corners in wage rates by using their considerable bargaining power over labor, and (2) foreign governments have purposely not regulated environmental externalities in an effort to help their economies. Both of these effects have kept foreign product prices competitive on the global market which then leads to: (1) lower supplier and resource expenses for industrialized nations that utilize outsourcing; and (2) lower retail prices which then trigger "excess consumption." Schor [50] defines excess consumption as additional consumption that is triggered by declines in the prices of goods and commodities caused by the particular organization of the global political economy.

Ironically, since policy makers and politicians stimulate business growth for the benefit of citizens an unintended effect of feeding the growth machine is the exporting of U.S. jobs overseas (off-shoring because of cheaper prices) contributing to higher levels of unemployment here and depressed (sweatshop) wages for developing countries. Higher unemployment in the U.S. provides politicians with more incentive to stimulate growth. In essence the global market imbalance helps feed the developed nations' business industrial growth which then contributes further to the global imbalance. In fact, neo-liberal economic policy reforms have further fueled this feedback cycle by encouraging excessive privatization and de-control of capital in developing countries [53].

The current structure of the global economy means that policies to internalize environmental costs via national regulations will be undercut by global competition. That is, free trade among nations with differing environmental and labor regulations will result in a standards-lowering competition. The net result is that more and more of global production will move to countries that do less and less environmental and labor protection [37].

\subsubsection{The Problems of Growth: The Loop You Can't Get Out of}

The business industrial growth model makes explicit some of the economic incentives that drive both company and consumer behavior. Companies must seek competitive advantages by offering unique, innovative products that consumers demand and/or, especially in the case of commodity products, they must be able to offer low prices. This competitive necessity drives business investment in technology, employment and marketing efforts.

Stopping the forces that drive this behavior may not be easy. First, technology investments improve productivity and allow companies to produce more with less labor. Business growth then becomes necessary simply to keep employment levels from dropping [54]. 
While the long-run dynamic of this system structure leads to side-effects or problem symptoms such as global inequality, environmental destruction, habitat loss, resource depletion, social injustice and war, each actor in the model (including the political decision makers) is compelled to act in their own short-term, individual interests (i.e. bounded rationality). Thus, the continued reliance on business growth or "the loop you can't get out of" [55] is supported by the mental models of citizens that demand employment opportunity, the politicians that demand re-election and the corporations who support and fund both groups.

\subsection{The New Trend: Sustainable Development and the New-Old Business Model}

The concept of sustainable development was first popularized in the 1987 report, Our Common Future [56]. The report brought into public consciousness a crucial concern - that global economic growth must be reconciled with the fact of limited natural resources and the dangers of environmental degradation. The report defined sustainable development as:

"Development that meets the needs of the present without compromising the ability of future generations to meet their own needs."

Since then the concept of sustainability has been expanded and is typically framed along three dimensions: social, economic, and environmental [57]. This is consistent with the definition of sustainability adopted by the United Nations:

Development is a multi-dimensional undertaking to achieve a higher quality of life for all people. Economic development, social development, and environmental protection are interdependent and mutually reinforcing components of sustainable development [58].

In recent years, the concept of sustainable development has been advanced as an opportunity for businesses to seek profits indirectly, that is, the notion that "companies can do well by focusing on doing good" (see [59-61]). Many corporations have indeed adopted this philosophy and have created strategies that promote "green products," and socially responsible behavior including efforts to ensure that global supply chains do not adversely impact the environment or unfairly exploit "sweat-shop" labor. Sustainable development has an intuitive appeal and it can be beneficial to profits for various reasons including: (1) consumers are increasingly attracted to green products and ethical behavior, (2) reducing the corporation's carbon footprint results in reduced energy costs, (3) searching for operations improvements to reduce environmental impacts also simultaneously reduces operations costs, and (4) reducing potential harm to the environment or other stakeholders reduces a company's risk to forthcoming legislation and legal actions, among others.

Despite these obvious benefits to organizations, sustainable development suffers from two major shortcomings. First, the legal definition of the corporation means that it is the job of management to satisfy shareholder (owner) interests and thus, maximizing shareholder value must continue to be the dominant objective of the firm [62]. If corporations do not continue to place profits first, then in competitive markets these firms obviously may not survive. Meanwhile Freeman et al. [63] argue that shareholder value is too narrow of a perspective and that a wiser long-term strategy is one that uses a stakeholder perspective and provides guidance to managers in their day-to-day operations. Nevertheless, many firms may still be reluctant to adopt sustainable development strategies where such actions are not deemed immediately necessary for short-term profits. In other words, if not prompted 
by government action the short-term incentive for many firms in many markets means that short-term profits and shareholder returns will still dominate much decision making.

Second, the effect of actually adopting sustainable development strategies means that companies will simply find more opportunities to grow. That is, if profit is still the underlying driving force in competitive economies, then sustainable development simply serves as another competitive weapon. Thus, sustainable development as it is now conceived is simply another business strategy that enables more growth [36,55]. Therefore, as with the case for technology solutions presented earlier, sustainable development must be re-conceptualized or used with other policies that balance or attenuate business growth or, the sustainability problem simply becomes worse.

\section{Solutions to the Fundamental Sustainability Problem}

As Hardin pointed out 44 years ago, the population problem is of the class of no technology solution problems. That is, exponential growth of world population must be dealt with directly, by changes in man's behavior, and not simply by technology, tools or advances in science. The fundamental sustainability problem, living within the limits of a finite planet indefinitely is also a no technology solution problem because both population and affluence are increasing exponentially and technology and markets alone are insufficient [64]. If the sustainability problem is not difficult enough an additional complication arises that is due to the general lack of understanding of how exponential growth behaves. Exponential growth baffles human judgment and intuition. To see the difficulty that comes with understanding exponential growth, see Appendix 2.

\subsection{Problem Recognition and Definition with Exponential Growth Problems}

Although the problem of global sustainability and limits to growth has been known for over 40 years (see [65]), there has been significant delay in fully recognizing, defining and accepting this problem by the general public, and even by many academics and thought leaders. This is a major problem because delay, in combination with growth against limits is a recipe for system overshoot and collapse [64]. Thus, a necessary prerequisite to achieving sustainability is to make sure that there is wide acceptance and understanding of the nature and severity of the problem.

In the exponential growth example where a resource (i.e., the bottle in Appendix 2) is depleted over a sixty (60) time unit duration, the resource carrying capacity remains $98 \%$ empty with only $10 \%$ of the time remaining until the carrying capacity is completely exhausted! This aspect of exponential growth means that most citizens and policy makers will not recognize the extent and severity of the problem of declining resources (see Note 1, Appendix 2). Not recognizing problems causes further delay and makes potential solutions even more costly and thus less appealing to the public who must then make greater short-term financial sacrifices [66]. Given our past history and our current political decision making structure, the likelihood of acceptance, adoption and implementation of solutions that benefit society in the longer-term, but impose costs in the short-term is very low [67]. In addition, not understanding exponential growth problems means that large energy firms and much of the public continue to believe that supply-side strategies (e.g. finding more oil) will allow us to continue with business as usual. As demonstrated in Appendix 2 (Note 2), this is not possible. 
After understanding some of the impediments that have delayed the sustainability problem definition phase, below are some suggested steps to get us moving in the right direction.

\subsection{Modified Capitalism: Or Markets Alone Can't Solve the Problem: But They Can Help with} Support from Government Policy

Schor [50] notes the apparent paradox that never before have the technological means to achieve sustainability existed, yet actual levels of ecological degradation and resource depletion are at record levels. For example, we have the technology to produce hybrid vehicles with much higher fuel efficiency yet few Americans are demanding and driving them. Figure 8 displays a causal loop diagram that shows a "success to the successful" system archetype pattern. If we start reading the diagram from a decreasing market price of gas it then follows that the demand for gas guzzlers increases. As the demand for gas guzzlers increases, production increases which then leads to a decreasing production cost per vehicle and a decreasing market price for gas guzzlers (e.g. SUVs) which then reinforces further increasing demand for gas guzzlers. In order to get off the SUV demand loop, one would need to create policy that, in effect, increases gas prices. This would have the effect of increasing demand and production and lowering cost for the more socially responsible hybrid vehicles. Unfortunately in a world driven by short-term economic incentives, policy such as a gas tax would not be politically feasible. However, there still exist socially beneficial public policies that could promote this behavior. For example, "fee-bates" have been suggested where consumers who choose to purchase a vehicle that gets below 30 miles per gallon, would be required to pay a fee. Consumers who purchased vehicles that get above 30 miles per gallon would then receive a rebate (see [68]).

Figure 8. Demand for Industrial Products: Government Intervention and Socially Responsible Behavior.

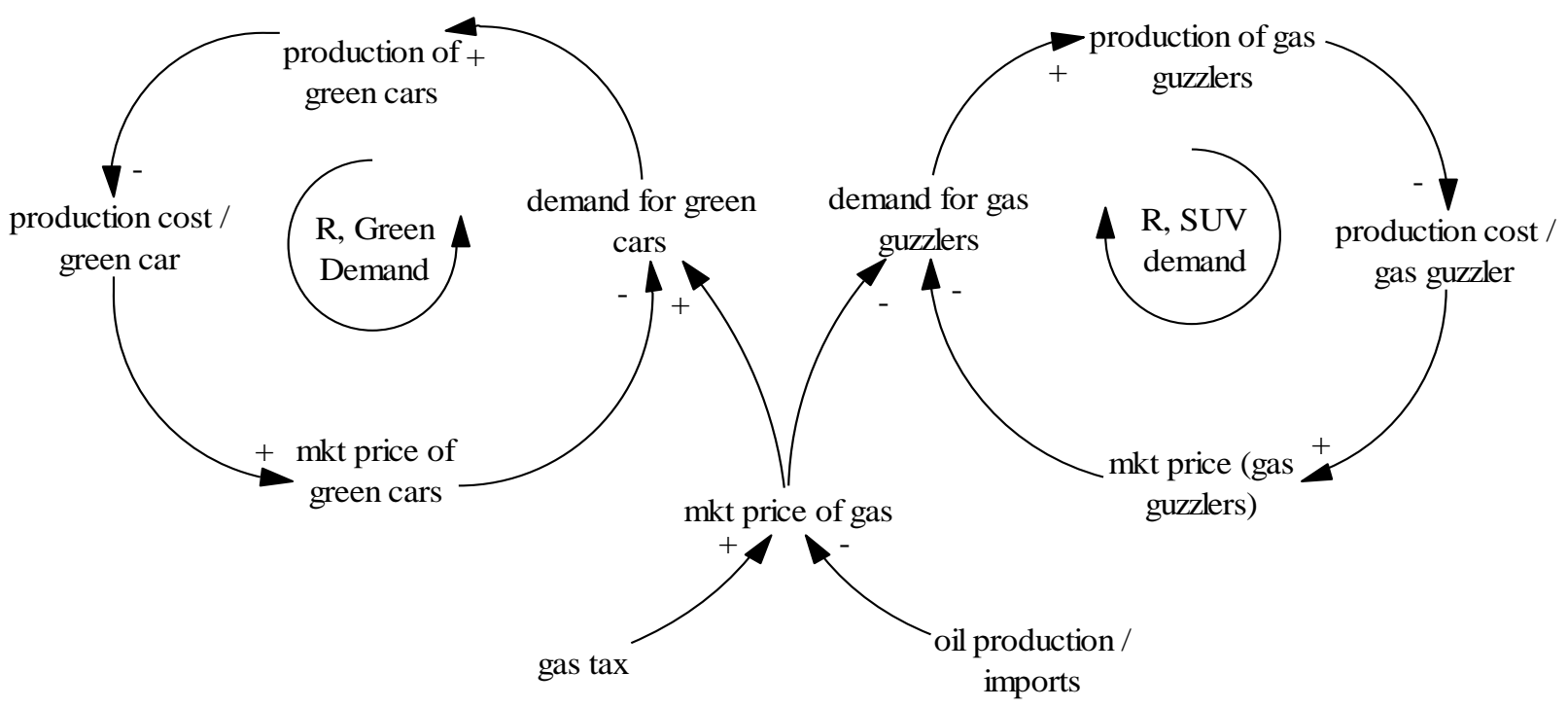

The largest issues that most impact all of us such as global climate change, habitat destruction, and resource depletion are not easily solved by the private market. Due to bounded rationality and our current economic incentives, the private market and vested interests, both companies and individuals 
will continue to seek projects that primarily benefit themselves in the short-run. The benefits received from long-term investments and activities that support the common good, like climate change, are simply too far into the future [67]. Obvious state interventions such as a new carbon tax would be welcomed by many "green," cutting-edge firms. However, a carbon tax, while benefiting the majority for the long-run will have a negative, short-term impact on some stakeholders. Thus, under our current democratic form of government, which requires a majority approval, such policy would face little chance of succeeding (p. 166 [67]).

Government interventions are also required to help manage many natural resource stocks and ecosystem services. The example from Section 2.2.2, Rebuilding Global, ITQ Fisheries, is a case in point. Establishing precautionary TAC to help rebuild fish stocks requires short-term sacrifices by the fishing community. Government intervention in the form of public/private transfers can help fisheries cope with short-term economic shortfalls [26]. Importantly, the government cost would only be short-term while fish stocks rebuild to sufficient levels. After that period, normal market forces can return and successful fisheries can even pay back government aid.

\subsection{Power to the People: Smart Government Requires Smart Citizens}

Modified capitalism requires a significant increase in the use of government policy to provide the necessary nudges to steer the free market in directions that are best for the common good. At present, there is a large segment of the U.S. population that is strictly opposed to larger government. For many, there is a feeling that government is too large, taxes are too great, and continued high levels of government involvement is simply inefficient and hinders the proper operation of the free market. As implicitly expressed in Figure 7, the public looks to policy makers to help stimulate the economy and keep employment levels high. In essence, each one of us is responsible for keeping the business growth loop going and driving our unsustainable world.

Instead of remaining in this harmful reinforcing feedback loop, sustainability and system thinking education must be a major priority to educate citizens, change mental models [36] and move toward both better government with modified capitalism [67], and toward reduced consumerism [50,54,69].

\subsection{Small is Beautiful: Communities as Centers for Economic Activity, Not Just Corporations}

According to Jackson [54] we must find ways to achieve balance between the self and our individual interests versus society and shared endeavor. Our collective interests and shared endeavors include the maintenance of public goods (e.g. natural stocks, and ecosystem services, etc.) and understanding the role they play for our mutual long-term benefit. At present government is in conflict with itself as its two main interests are at odds: (1) the role of government to ensure that long-term public goods are not undermined by short-term private interests, and (2) the current role of government as an agent to stimulate and maintain economic growth [54].

While education is crucial for helping us change our mental models and promoting a new paradigm of sustainability and business, there are other strong influences that shape our conventional wisdom. Corporations exert a tremendous influence on our attitudes through advertising, promotion, and funding of cultural and sport activities. In addition, because of their vast wealth, corporations and the wealthiest of society are able to influence the political discourse through political campaign funding 
and through legal influence of our political system directly (lobbying for legislation). To mitigate some of this harmful influence that reinforces business growth, there are two necessary steps.

First, while freedom of speech is a necessary prerequisite for a proper functioning democracy, we should return to the concept of freedom of speech for individual citizens and groups of citizens and away from the concept of freedom of speech for corporations. Campaign finance reform and other efforts are moves in the right direction.

Second, a move is necessary away from companies and corporations' influence and the promotion of the individual as "nothing more than a consumer" toward a new view of the individual as an authentic human. Authentic living means a life less directed by the cultural other (corporate societal structure) and more directed through freer choice by the self. As stated by Ehrenfeld (p. 121, [27]), "with authenticity modern humans can possibly break free from the grip that technology has upon them, at least long enough to begin caring for themselves, other humans, and the world of nature. Without such care, sustainability will always be unavailable."

A community as a center for economic activity means (1) that work in a community is a human activity that helps develop the person, (2) human relationships, and the development of social capital is important, and (3) people have and develop a greater appreciation of place. A community assigns greater value to human relationships and an economy built around community, as it is intended here, resembles the concept of Buddhist economics. Specifically, the Buddhist point of view takes the function of work to consist of at least 3 purposes: (1) to give a man a chance to develop and utilize his skills and intelligence, (2) to enable him to overcome his ego-centeredness by joining with other people in a common task, and (3) to bring forth the goods and services needed for a worthwhile existence (p. 38 [69]).

Buddhist economics is very different from the economics of modern materialism. The Buddhist sees the essence of civilization not in the multiplication of wants but in the purification of character. Meanwhile, character is formed primarily by a man's work (p. 39 [69]). Flowing from this line of thinking or philosophy is the realization that the quantity of consumption can be reduced by changes to human goals and desires. A greater emphasis on community can lead to less "over-consumption," and less "competitive consumption." The community as a center for economic activity means greater emphasis on locally owned, entrepreneurial, small-scale businesses that may be structured as co-ops (or community owned and operated, see [70]). Consumer/citizens would be inclined to work and purchase locally since they would have greater incentive to invest in their communities and benefit from reciprocal cooperation. In fact, grassroots efforts have started along this path through innovative ideas like community dollars. Trends in resource scarcity, in particular the approaching peak oil crisis, will likely make globally sourced products less competitively priced and further encourage community-based economic activity. Even in the U.S., there are already trends in locally grown food [71].

In addition, the community as a center for economic activity means less emphasis on the use of technology to boost productivity, with its concomitant replacement or demeaning of labor, and a greater emphasis on meaningful work and service work. A change in the structure of economic activity with a greater potential for meaningful work may generate effects such as a greater sense of wellbeing, more leisure and less consumption and less emphasis on a materialistic culture [27,50,54]. Government sponsored investment in ecosystem health, infrastructure, and public works through 
modified capitalism can promote our ecological system health and generate long-term economic benefits while also providing another avenue for employment [67].

\subsection{Community Focus as Solutions for both CPR and Unsustainability Problems}

The fundamental sustainability problem can be viewed as a special case of the tragedy of the commons or as a series of aggregate CPR problems. For example, the largest of our CPR problems include managing our oceans and global atmosphere. The solution to CPR problems advanced by Ostrom and colleagues [10-13] rests on the evidence of numerous successfully managed communities of cooperating individuals. However, community management of global CPRs is enormously difficult because global CPRs span wide geographic areas and political boundaries. The specific mechanisms of cooperation are thus more difficult to implement. Nevertheless, this approach, focusing on communities, can allow us to alter our human and economic goals and can help change the focus of economic activity providing a more balanced economy that is not as dependent on material throughput.

When people live in communities and find meaningful work independent from large companies and with less dependence on material goods, they can achieve more direct and longer lasting forms of happiness via stronger social ties and better work life balance. Sustainability solutions must emphasize social equity since the ultimate success of any socio-economic system rests on achieving long-term happiness, quality of life, and social justice for all humans.

\section{Conclusions}

The problem of un-sustainability is a problem of changing mental models and paradigms. Currently the world is driven by two major schools of thought: neo-liberal economics and sustainable development. Policy makers and national governments are pushed by neo-liberal economic thinking to promote economic growth, globalization and free trade. This approach is touted as an answer to poverty, unemployment and even as an answer to environmental problems and un-sustainability.

Although one can point to years and years of empirical data that suggest that economic growth is beneficial for mankind, the world has been changing. Increasingly, when more and more of our natural resource stocks are pushed to and beyond their limits, it is becoming clearer that our current paradigm of growth is no longer helping mankind (see [37]). Adam Smith's notion of the invisible hand, that individual choice is best for the common good, is not always true. On the other hand, the counter-philosophy of sustainable development, seeking to do good, we will also do well, is also problematic. It is a problem because it is currently decoupled from good government policy and social responsibility and thus it is simply being used by business as a strategy for more business growth. Because of this, sustainable development is really being implemented as sustainable growth, a contradiction or oxymoron.

Sustainable growth gives people a false sense of security. Because corporations appear to be taking responsibility for sustainability people feel the job is being done and they don't need to change their own behavior. But, corporations are designed for profit. When corporations take all of the responsibility for sustainability we get the business industrial growth model with all of its consequences and problem symptoms. 


\section{Global Institutions and the Tragedy of the Commons}

The tragedy of the commons contains two important, underlying principles that cause this problem behavior: (1) bounded rationality, and (2) growth against limits. A tragedy of the commons problem can arise whenever systems are (1) arranged in smaller components that are designed with agents that seek individual interests, and (2) the actions of the agents create growth and (3) there are physical limits.

Because our socio-economic world is divided up by countries, and because our important environmental measures are global, such as $\mathrm{CO}_{2}$ output, we could have a tragedy of the commons scenario developing in the future. Currently, the United Nations has sought to develop a shared understanding and non-binding agreements among nations to work toward our global sustainability problems. However, agreements are difficult because each nation can benefit from economic growth while the cost is shared by all.

There is still cause for hope. Universities are beginning to teach sustainability and companies are developing necessary, but not sufficient, technologies. It is imperative however that we change how we live, with a greater focus on community activity, modified capitalism, and a better educated population.

\section{Acknowledgments}

I would like to thank Michael Gent for kindly sharing his knowledge on neo-liberal economics and Girish Shambu for his generous help and insight on consumerism.

\section{Conflict of Interest}

The author declares no conflict of interest.

\section{References}

1. Hardin, G. Tragedy of the Commons. Science 1968, 162, 1243-1248.

2. von Neumann, J.; Morgenstern, O. Theory of Games and Economic Behavior; Princeton University Press: Princeton, NJ, USA, 1947; p. 11.

3. Kast, F.E.; Rosenzweig, J.E. General systems theory: Applications for organization and management. Acad. Manag. Rev. 1972, 15, 447-465.

4. Sterman, J.D. Business Dynamics: Systems Thinking and Modeling for a Complex World; Irwin/McGraw-Hill: Boston, MA, USA, 2000.

5. Simon, H.A. Administrative Behavior, 3rd ed.; The Free Press: New York, NY, USA, 1976.

6. Morecroft, J.D.W. Rationality in the analysis of behavioral simulation models. Manag. Sci. 1985, 31, 900-916.

7. Meadows, D.H. Thinking in Systems: A Primer; Chelsea Green Publishing: White River Junction, VT, USA, 2008.

8. Feeny, D.; Berkes, F.; McCay, B.J.; Acheson, J.M. The tragedy of the commons: Twenty-two years later. Hum Ecol. 1990, 18, 1-19.

9. Hardin, G. Extensions of "The tragedy of the commons". Science 1998, 280, 682-683. 
10. Ostrom, E.; Burger, J.; Field, C.B.; Norgaard, R.B.; Policansky, D. Revisiting the commons: Local lessons, global challenges. Science 1999, 284, 278-282.

11. Ostrom, E. Coping with tragedies of the commons. Annu. Rev. Polit. Sci. 1999, 2, 493-535.

12. Ostrom, E. Governing the Commons: The Evolution of Institutions for Collective Action; Cambridge University Press: New York, NY, USA, 1990.

13. Ostrom, E.; Gardner, R.; Walker, J. Rules, Games, and Common-Pool Resources; University of Michigan Press: Ann Arbor, MI, USA, 1994.

14. Nowak, M.A.; Highfield, R. Super Cooperators: Altruism, Evolution, and Why We Need Each Other to Succeed; Free Press: New York, USA, 2012.

15. Nowak, M.A. Why we help. Sci Am. 2012, 307, 34-39.

16. Wingard, J.D. Community transferable quotas: Internalizing externalities and minimizing social impacts of fisheries management. Hum. Organ. 2000, 59, 48-57.

17. Costello, C.; Gaines, S.D.; Lynham, J. Can catch shares prevent fisheries collapse? Science 2008, $321,1678-1681$.

18. Festa, D.; Regas, D.; Boomhower, J. Sharing the catch, conserving the fish. Issues Sci. Technol. 2008, Winter, 75-84.

19. Arnason, R. Property rights in fisheries: Iceland's experience with ITQs. Rev. Fish. Biol. Fisher. 2005, 15, 243-264.

20. Chu, C. Thirty years later: The global growth of ITQs and their influence on stock status in marine fisheries. Fish Fish. 2008, 10, 1-14.

21. Dewees, C.M. Assessment of the implementation of individual transferable quotas in New Zealand's inshore fishery. N. Am. J. Fish. Manag. 1989, 9, 131-139.

22. Branch, T.A.; Hilborn, R.; Haynie, A.C.; Fay, G.; Flynn, L.; Griffiths, J.; Marshall, K.N.; Randall, J.K.; Scheuerell, J.M.; Ward, E.J. Fleet dynamics and fishermen behavior: Lessons for fisheries managers. Can. J. Fish. Aquat. Sci. 2006, 63, 1647-1668.

23. McCay, B.J.; Creed, C.F.; Finlayson, A.C.; Apostle, R.; Mikalsen, K. Individual transferable quotas (ITQs) in Canadian and U.S. fisheries. Ocean Coast. Manag. 1995, 28, 85-115.

24. Copes, P. A critical review of the individual quota as a device in fisheries management. Land Econ. 1986, 62, 278-291.

25. Bromley, D.W. Abdicating responsibility: the deceits of fisheries policy. Fisheries 2009, 34, 280-290.

26. Garrity, E.J. System dynamics modeling of individual transferrable quota fisheries and suggestions for rebuilding stocks. Sustainability 2011, 3, 184-215.

27. Ehrenfeld, J.R. Sustainability by Design: A Subversive Strategy for Transforming Our Consumer Culture; Yale University Press: New Haven, CT, USA, 2008.

28. Cavlovic, T.A.; Baker, K.H.; Berrens, R.P.; Gawande, K. A meta-analysis of environmental Kuznets curve studies. Agr. Resour. Econ. Rev. 2000, 29, 32-42.

29. Grossman, G.; Krueger, A. Economic growth and the environment. Q. J. Econ. 1995, 110, 353-377.

30. Stern, D.I. Progress on the environmental Kuznets curve? Environ. Dev. Econ. 1998, 3, 173-196. 
31. Moll, A.P.J.; Spaargaren, G. Ecological modernization theory in debate: A review. Environ. Polit. 2000, 9, 17-49.

32. Graedel, T.; Allenby, B. Industrial Ecology; Prentice Hall: Englewood Cliffs, NJ, USA, 1995.

33. York, R.; Rosa, E.A.; Dietz, T. The ecological footprint intensity of national economies. J. Ind. Ecol. 2005, 8, 139-154.

34. Commoner, B. A Bulletin Dialogue: On "The Closing Circle"-Response. B. Atom. Sci. 1972, 28, 17-56.

35. Chertow, M.R. The IPAT equation and its variants. J. Ind. Ecol. 2000, 4, 13-29.

36. Sterman, J. Sustaining Sustainability: Creating a Systems Science in a Fragmented Academy and Polarized World. In Sustainability Science: The Emerging Paradigm and the Urban Environment; Weinstein, M., Turner, R.E., Eds.; Springer: Berlin, Germany, 2012; pp. 21-58.

37. Daly, H. Beyond Growth: The Economics of Sustainable Development; Beacon Press: Boston, MA, USA, 1996.

38. Worldometers. World population. Available online: http://worldometers.info/world-population/ (accessed on 1 July 2012).

39. Worldbank. Databank. Available online: http://databank.worldbank.org/ddp/home.do (accessed on 1 July 2012).

40. Worldpop. World population. Available online: http://www.census.gov/population/international /data/worldpop/table_population.php (accessed on 1 July 2012).

41. Indexmundi.com. GDP Real Growth Rate. Available online: http://www.indexmundi.com/g/g. aspx $? c=x x \& v=66$ (accessed on 23 July 2012).

42. CIA World Factbook. Available online: https://www.cia.gov/library/publications/the-worldfactbook/geos/xx.html (accessed on 23 July 2012).

43. York, R.; Rosa, E.A.; Dietz, T. STIRPAT, IPAT and ImPACT: Analytic tools for unpacking the driving forces of environmental impacts. Ecol. Econ. 2003, 46, 351-365.

44. Wei, T. What STIRPAT tells about effects of population and affluence on the environment? Ecol. Econ. 2011, 72, 70-74.

45. Theis, T.; Tomkin, J. Sustainability: A Comprehensive Foundation; University of Illinois: Urbana-Champagne, Il, USA, 2012. Available online: http://www.illinoiseducator.uillinois.edu/ opentxt/sustainability.htm (accessed on 15 July 2012).

46. Theis, T. Human consumption patterns and the rebound effect, Connections. Available online: http://cnx.org/content/m41191/latest/ (accessed on 15, July, 2012).

47. Jevons, W.S. The Coal Question. 1866. Library of Economics and Liberty. Available online: http://www.econlib.org/library/YPDBooks/Jevons/jvnCQ.html (accessed on 15 July 2012).

48. Jevons, W.S. Of the economy of fuel. Organ. Environ. 2001, 14, 99-104.

49. Dahmus, J.B.; Gutowski, T.G. Can efficiency improvements reduce resource consumption? A historical analysis of ten activities. J. Ind. Ecol. 2012, accepted for publication.

50. Schor, J.B. Prices and quantities: Unsustainable consumption and the global economy. Ecol. Econ. 2005, 55, 309-320.

51. Sterman, J.D. Learning from evidence in a complex world. Am. J. Public Health 2006, 96, 505-514. 
52. Schor, J.B. The Overspent American: Upscaling, Downshifting and the New Consumer; Basic Books: New York, NY, USA, 1998.

53. Stiglitz, J.E. Globalization and Its Discontents; Norton: New York, NY, USA, 2002.

54. Jackson, T. Prosperity Without Growth: Economics for a Finite Planet; Earthscan: London, UK, 2009.

55. Forrester, J. The loop you can't get out of. MIT Sloan Manag. Rev. 2009, 50, 9-12.

56. World Commission on Environment and Development (WCED). Our Common Future; Oxford University Press: New York, NY, USA, 1987.

57. Kuhlman, T.; Farrington, J. What is sustainability? Sustainability 2010, 2, 3436-3448.

58. United Nations. Agenda for Development; United Nations: New York, NY, USA, 1997.

59. Nattrass, B.; Altomare, M. The Natural Step for Business: Wealth, Ecology and the Evolutionary Corporation, 2nd ed.; New Society Publishers: Garbriola Island, Canada, 2001.

60. Esty, D.C.; Winston, A.S. Green to Gold: How Smart Companies Use Environmental Strategy to Innovate, Create Value, and Build Competitive Advantage; Yale University Press: New Haven, CT, 2006.

61. Lazlo, C. Sustainable Value: How the World's Leading Companies Are Doing Well by Doing Good; Stanford Business Books: Stanford, CA, 2008.

62. Sundaram, A.K. The corporate objective revisited. Organ. Sci. 2004, 15, 350-363.

63. Freeman, R.E.; Wicks, A.C.; Parmar, B. Stakeholder theory and the "Corporate objective revisited". Organ. Sci. 2004, 15, 364-369.

64. Meadows, D.; Randers, J.; Meadows, D. Limits to Growth: The 30-Year Update; Chelsea Green Publishing: White River Junction, VT, USA, 2004.

65. Meadows, D.H.; Meadows, D.L.; Randers, J.; Behrens, W.W., III. The Limits to Growth; Universe Books: New York, NY, 1972.

66. Ludwig, D.; Hilborn, R.; Walters, C. Uncertainty, resource exploitation, and conservation: Lessons from history. Science 1993, 260, 17.

67. Randers, J. 2052: A Global Forecast for the Next Forty Years; Chelsea Green Publishing: White River Junction, VT, USA, 2012.

68. Hawken, P.; Lovins, A.; Lovins, L.H. Natural Capitalism: Creating the Next Industrial Revolution; Little Brown and Company: New York, NY, USA, 1999.

69. Schumacher, E.F. Small Is Beautiful: Economics As If People Mattered; Hartley and Marks: Point Roberts, WA, USA, 1973.

70. Evergreen Cooperatives. Available online: http://evergreencooperatives.com (accessed on 15 July 2012).

71. Metcalf, S.; Widener, M. Growing Buffalo's capacity for local food: A systems framework for sustainable agriculture. Appl. Geogr. 2011, 31, 1242-1251.

\section{Appendix 1. Policy Resistance}

Policy resistance is the term that describes how complex systems react to alter the intended objective of policy interventions [1]. Policy resistance is caused by the mismatch between our simple mental models of the world and the complexity of our highly interconnected systems [2]. Although our 
educational system is designed along disciplinary specialties, the problems encountered in the real world span biological, cultural, economic, geographic, physical, and political boundaries (among many other categories). Although people tend to view events in a simple cause and effect structure the reality is that our actions impact the environment and generate additional side effects that we don't anticipate because our thinking and mental models are too narrow [2].

Since the system structure and information flows generate the long-run behavior we observe, policies aimed at problem symptoms will alter the system structure and produce compensating feedbacks [3].

Social systems are especially prone to policy resistance. Social systems that involve humans as fundamental components are among the most complicated of systems. This is because humans are intelligent actors who respond to changes in system structure or decision policy. For example, increases in better technologies have led to cleaner cars but not to less pollution generated. This is because consumers have acquired more vehicles, larger vehicles (e.g. substitution to sport utility vehicles), and have driven more miles per vehicle [4]. Such phenomena are not special cases but reflect a fundamental property of complex systems (see Box 1).

Box 1. Examples of Policy Resistance, adapted from [3].

- Road building programs designed to reduce congestion and amount of traffic have had the opposite effect: increasing traffic, delays and pollution. This is because people respond to the increased capacity of roads by adjusting their behavior; driving more, taking longer commutes, and even buying more vehicles [3].

- Improvements in residential energy technologies have not led to reductions in household energy usage because consumers have reacted by building bigger homes and using more energy requiring appliances [4].

- Antibiotics have stimulated the evolution of drug-resistant pathogens making us less safe from disease and infection [5].

- Pesticides and herbicides have not only killed off target populations but have also destroyed natural predators, led to resistant forms of pests and have factored up the food chain to destroy higher life forms including, in some cases, humans [6].

- Moore's Law has shown that the number of integrated circuits doubles approximately every two years (see [7]). But, such exponential growth in computing power would mean that organizations would need fewer computers. However, the opposite has happened. Advances in computing power simply mean that individuals and organizations can acquire more computing power, and do so to remain competitive.

\section{References}

1. Forrester, J.W. Counterintuitive behavior of social systems. Technol. Rev. 1971, 73, 52-68.

2. Sterman, J. Sustaining sustainability: Creating a systems science in a fragmented academy and polarized world. In Sustainability Science: The Emerging Paradigm and the Urban Environment; Weinstein, M., Turner, R.E., Eds.; Springer: Berlin, Germany, 2012; pp. 21-58. 
3. Sterman, J.D. Business Dynamics: Systems Thinking and Modeling for a Complex World; Irwin/McGraw-Hill: Boston, MA, USA, 2000.

4. Schor, J.B. Prices and quantities: Unsustainable consumption and the global economy. Ecol. Econ. 2005, 55, 309-320.

5. Fong, I.; Drlica, K. Reemergence of Established Pathogens in the 21st Century; Kluwer: Plenum, NY, USA, 2003.

6. Palumbi, S. Humans as the world's greatest evolutionary force. Science 2001, 293, 1786-1790.

7. Moore's Law, Wikipedia.org. Available online: http://en.wikipedia.org/wiki/Moore's_law (accessed on 30 July 2012).

\section{Appendix 2. Exponential Growth}

Table 1. If we start with 1 bacterium in a bottle at 11 am and the bacteria grow at an exponential rate such that they double every minute, and fill the bottle at $12 \mathrm{pm}$, at what point will the bottle be half-full? [1].

\begin{tabular}{llll}
\hline Time & Number of bacteria & Bottle, \% full & Bottle, \% empty \\
\hline $11: 00$ am & 1 & $0 \%$ & $100 \%$ \\
$11: 01 \mathrm{am}$ & 2 & $0 \%$ & $100 \%$ \\
& 53 minutes later, & & \\
$11: 54 \mathrm{am}$ & $18,014,398,509,482,000$ & $2 \%$ & $98 \%$ \\
$11: 55 \mathrm{am}$ & $36,028,797,018,964,000$ & $3 \%$ & $97 \%$ \\
$11: 56 \mathrm{am}$ & $72,057,594,037,927,900$ & $6 \%$ & $94 \%$ \\
$11: 57 \mathrm{am}$ & $144,115,188,075,856,000$ & $13 \%$ & $87 \%$ \\
$11: 58 \mathrm{am}$ & $288,230,376,151,712,000$ & $25 \%$ & $75 \%$ \\
$11: 59 \mathrm{am}$ & $576,460,752,303,423,000$ & $50 \%$ & $50 \%$ \\
$12: 00 \mathrm{pm}$ & $\mathbf{1 , 1 5 2 , 9 2 1 , 5 0 4 , 6 0 6 , 8 5 0 , 0 0 0}$ & $\mathbf{1 0 0 \%}$ full & $\mathbf{0 \%}$ \\
\hline
\end{tabular}

Note 1: Empirical forecasting and problem definition: The bottle fills for 1 hour, from 11 am until full at 12pm. At 11:54am, the bottle is still $98 \%$ empty!

Note 2: Supply-side solutions: If at the last minute, 11:59, 3 new bottles are discovered, for a total of 4 bottles or 4 times the original supply, then how long does the new supply last? Answer: 2 bottles are filled at 12:01pm and by 12:02pm, all 4 bottles are filled.

\section{References}

1. Bartlett, A. Exponential Growth, youtube.com. Available online: at http://www.youtube.com/ watch?v=F-QA2rkpBSY (accessed on 23 July 2012).

(C) 2012 by the authors; licensee MDPI, Basel, Switzerland. This article is an open access article distributed under the terms and conditions of the Creative Commons Attribution license (http://creativecommons.org/licenses/by/3.0/). 